\title{
Pemanfaatan Media Bergambar Pada Pembelajaran Subtema Hewan Disekitarku Terhadap Proses Pembelajaran Siswa Autis Di Sekolah Dasar Islam Terpadu Insan Mulia Merangin
}

\author{
Sri Sunarsih \\ Pascasarjana Universitas Jambi, Indonesia
}

\begin{abstract}
This research aims to explore the utilization of pictorial media in animal subtheme learning to the learning process of autistic students at SDIT Insan Mulia Merangin including the utilization of pictorial media in the language skills of autistic students and using animal images to count using qualitative research methods. The data collection techniques in this study are observations using observation instruments set by researchers, interviews of principals and parents of autistic students and documentation including previous studies, student data and other supporting documents. The data collected is analysed by using techniques in qualitative research. The results showed that pictorial media is able to improve the language skills of autistic students and the ability to count.
\end{abstract}

Keywords : pictorial media, language skills, counting skills, autistic students

\section{Pendahuluan}

Autisme adalah gangguan neurologis kompleks yang memiliki efek seumur hidup pada perkembangan berbagai kemampuan dan keterampilan. Kurangnya komunikasi dan interaksi sosial, serta pola yang tidak biasa seperti perilaku, minat, dan aktifitas. Gejala-gejala autis ini dapat berkisar dari gangguan ringan hingga berat di beberapa daerah berkembang, seperti di kabupaten Merangin. Banyak profesional di bidang medis, pendidikan, dan bidang kejuruan masih menemukan bagaimana kasus autis menarik perhatian dan bagaimana bekerja secara efektif dengan seorang penderita autis.

Terkait dengan permasalahan autis seperti yang disebutkan diatas, di SDIT Insan Mulia Merangin terdapat beberapa siswa yang menunjukan gejala autis. Siswa autis ini diklasifikasikan ke dalam autis ringan yang termasuk siswa berkebutuhan khusus ke dalam sindrom asperger, dimana menurut Cohen dan Bolton (1993) dalam Hardian J (2008), bahwa autis ringan ini adalah kondisi dimana anak autis menunjukan adanya kontak mata walaupun tidak berlangsung lama, dapat memberikan respon ketika dipanggil namanya, menunjukan ekspresi-ekspresi wajah, dalam berkomunikasi secara dua arah namun tidak berlangsung lama. Sindrom asperger sendiri menurut Handoyo (2008) adalah anak kurang 


\section{Sri Sunarsih}

berinteraksi sosial, meskipun dalam berkomunikasi cukup baik, namun anak sering menunjukan perilaku yang tidak wajar dan minat yang terbatas.

Siswa autis ini mempunyai sifat-sifat dengan menunjukan ciri-ciri sebagai siswa autis yaitu bicaranya secara verbal sulit dimengerti oleh siswa lain, tidak mau bergaul dan bermain dengan siswa lain, kadang suka berbicara dan tertawa sendiri, kerjanya hanya menggambar buku-buku yang dia punya, senang menyendiri dan jika hendak makan dia akan selalu mencium makanan tersebut. Ada diantara kelas yang lain, teman-teman sekelasnya sering mengejek. Hingga kadang membuat siswa autis ini menangis tetapi ada siswa autis yang sama sekali tidak peduli dengan ejekan teman-temannya.Tidak mempunyai ketertarikan dalam mengikuti pelajaran yang diberikan oleh gurunya. Mereka pun hanya bisa dekat dengan guru kelas saja. Begitu sulit beradaptasi dengan lingkungan dimana mereka berada. Tidak mudah seorang guru untuk mengajarkan kepada mereka tentang ilmu pengetahuan secara verbal, karena secara akademik mereka tidak mempunyai kemampuan apapun.

Untuk menangani siswa-siswa dengan gejala seperti diatas, guru harus mempunyai berbagai keterampilan khusus terkait pembelajaran siswa autis. Berbagai strategi dan pendekatan yang dilakukan guru dalam pembelajaran untuk menghasilkan atau mendapatkan mutu yang bagus. Latar belakang guru kelas yang bukan berasal dari pendidikan guru sekolah luar biasa yang khusus menangani siswa autis, sehingga guru sering mengalami hambatan dalam menyampaikan materi pelajaran yang sedang berlangsung. Siswa autis membutuhkan perhatian khusus dalam setiap proses pembelajaran. SDIT Insan Mulia belum lama berdiri, belum bisa memenuhi atau memberdayakan guru atau sdm lebih banyak karena terkendala oleh biaya operasional yang di hadapinya.

Untuk memperoleh capai hasil belajar dan menunjang lancar proses pembelajaran, guru harus menggunakan berbagai strategi dan pendekatan dalam pembelajaran untuk menghasilkan atau mendapatkan mutu yang bagus.

Berdasarkan pengamatan yang peneliti laksanakan sehari-hari, guru sering mengalami kesulitan menyampaikan materi pembelajaran kepada siswa autis, dengan keterbatasan sarana SDIT Insan Mulia merangin, siswa-siswa ini sering terabaikan dan terhambat dalam hal pembelajaran. siswa autis ini cenderung menyukai gambar-gambar yang ada dalam buku-buku pelajaran daripada membaca tulisan-tulisan yang memenuhi buku paket. Siswa autis ini sering 
terpaku pada satu benda yang disukainya, dengan melihat gambar-gambar yang terdapat dalam bukunya, seringkali siswa ini menyalin gambar tersebut kedalam buku tulisnya.

Media bergambar ini dimanfaatkan untuk menyelidiki apakah program belajar siswa autis dapat menghasilkan peningkatan perkembangan belajar dan bersosial dan mungkin pada siswa normal lainnya dengan perlakuan serupa selama proses pembelajaran. Jenis media bergambar baru-baru ini dimanfaatkan untuk digunakan pada penderita autisme adalah media bergambar berupa poster, gambar visual dan gambar audio visual atau video.

Berdasarkan penjelasan latar belakang diatas maka peneliti mengambil penelitian yang berkenaan dengan pemanfaatan media bergambar untuk pembelajaran siswa autis dengan fokus penelitian pada pemanfaatan media bergambar pada pembelajaran subtema hewan disekitarku terhadap proses pembelajaran siswa autis di SDIT Insan Mulia Merangin meliputi:

1) Pemanfaatan media bergambar dalam kemampuan bahasa siswa autis, menyebutkan namanama hewan yang ada disekitar.

2) Pemanfaatan media bergambar dalam menggunakan gambar-gambar hewan untuk menghitung.

\section{Landasan Teori}

\section{Pengertian Autisme}

Istilah "autisme" pertama kali diperkenalkan pada tahun 1943 oleh Leo Kanner, seorang psikiater dari John Hopkins University yang menangani sekelompok anak-anak yang mengalami kelainan sosial yang berat, hambatan komunikasi dan masalah perilaku. Anak-anak ini menunjukkan sifat menarik diri (withdrawal), membisu, berperilaku dengan aktivitas repetitif (berulang-ulang) dan stereotipik (klise) serta senantiasa memalingkan pandangannya dari orang lain.

Secara etimologi (ilmu asal kata): anak autis adalah anak yang memiliki gangguan perkembangan dalam dunianya sendiri. Seperti kita ketahui banyak istilah yang muncul mengenai gangguan perkembangan. Autisme yaitu nama gangguan perkembangan komunikasi, sosial, perilaku pada anak (LeoKanner \&Asperger, 1943).

World Health Organization's International Classification of Diseases (ICD-10) mendefinisikan autisme khususnya childhood autism sebagai adanya keabnormalan dan atau gangguan perkembangan yang muncul sebelum usia tiga tahun dengan tipe karakteristik tidak 


\section{Sri Sunarsih}

normalnya tiga bidang yaitu interaksi sosial, komunikasi, dan perilaku yang diulang-ulang (World Health Organozation, 1992, p.253,). Anak autis termasuk salah satu jenis Anak Berkebutuhan Khusus (ABK) yang mengalami gangguan neurobiologis dengan adanya hambatan fungsi syaraf otak yang berhubungan dengan fungsi komunikasi, motorik sosial dan perhatian. Hambatan yang dialami anak autis merupakan kombinasi dari beberapa gangguan perkembangan syaraf otak dan perilaku siswa yang muncul pada tiga tahun pertama usia anak. Sedangkan sindrom adalah salah satu gejala autisme dimana penderitanya memiliki kesulitan berkomunikasi dengan lingkungannya, sehingga kurang kurang bisa diterima (Marganingtyas, 2014). Menurut Wihendra (2008), gejala asperger ini mulai terlihat saat seorang anak berusia 18 bulan, tapi semuanya baru benar-benar bisa dipastikan setelah anak berusia kurang lebih tiga tahun. Gejala-gejala umum asperger sendiri menurut Marganingtyas (2014) diantaranya adalah sulit berinteraksi dengan orang lain, memiliki empati, memahami sebuah peristiwa tapi tidak bisa memberikan respons yang umum dilakukan orang-orang. Kalau secara penampakan fisik, anakanak yang mengidap jenis penyakit autis tipe ini masih bisa berkomunikasi secara normal tapi tidak menampakkan ekspresi, kecenderungan mendiskusikan diri sendiri ataupun hal-hal yang dianggapnya menarik.

Sutadi (2002), menjelaskan bahwa yang dimaksud autistik adalah gangguan perkembangan neurobiologist berat yang mempengaruhi cara seseorang untuk berkomunikasi dan berelasi (berhubungan dengan orang lain). Penyandang autisme tidak dapat berhubungan dengan orang lain secara berarti, serta kemampuannya untuk membangun hubungan dengan orang lain terganggu karena ketidakmampuannya untuk berkomunikasi dan mengerti perasaan orang lain, penyandang autis memiliki gangguan pada interaksi sosial, komunikasi (baik verbal maupun non-verbal), imajinasi, pola perilaku repetitive dan resistensi terhadap perubahan pada rutinitas. Ika Widyawati (2001) menjelaskan bahwa autis merupakan gangguan perkembangan pervasive/Pervasive Developmental Disorder (PDD) atau disebut Autism Specrtum Disorder (ASD) yang ditandai dengan adanya abnormalitas dan atau hendaya perkembangan yang muncul sebelum usia 3 tahun, mempunyai fungsi yang abnormal dalam 3 bidang,yaitu interaksi: sosial, komunikasi, dan perilaku yang terbatas (restriktif) dan berulang (repetitif).

Menurut kriteria diagnostik dalam DSM IV (ElliottGR. Autistic Disorder and Other Pervasive Developmental Disorders. In: Rudolph CD, RudolphAM. Rudolph's Pediatrics, 21st ed. McGraw-Hill: NewYork, 2003. P.498-500) karakteristik penderita adalah : 
1. Gangguan kualitatif dalam interaksi sosial yang timbal balik, tidak mampu menjalin interaksi social yang cukup memadai: kontak mata sangat kurang, ekspresi muka kurang hidup, gerak-gerik yang kurang tertuju.

a. Tak bisa bermain dengan teman sebaya.

b. Tak dapat merasakan apa yang dirasakan orang lain.

c. Kurangnya hubungan sosial dan emosional yang timbal balik.

2. Gangguan kualitatif dalam bidang komunikasi

a. Bicara terlambat atau bahkan sama sekali tak berkembang (dan tidak ada usaha untuk mengimbangi komunikasi dengan cara lain tanpa bicara)

b. Bila bisa bicara, bicara tidak dipakai untuk komunikasi

c. Sering menggunakan bahasa aneh yang diulang-ulang

d. Cara bermain kurang variatif, kurang imajinatif, dan kurang bisa meniru

3. Suatu pola yang dipertahankan dan diulang-ulang dari perilaku, minat, dan kegiatan.

a. Mempertahankan satu minat atau lebih, dengan cara yang sangat khas dan berlebihan.

b. Terpaku pada suatu kegiatan yang ritualistic atau rutinitas yang tak ada gunanya.

c. Ada gerakan aneh yang khas dan diulang-ulang.

d. Seringkali terpukau pada bagian-bagian benda.

Bila gejala autisme dapat dideteksi sejak dini dan kemudian dilakukan penanganan yang tepat dan intensif, kita dapat membantu anak autis untuk perkembang secara optimal.

\section{Klasifikasi Autis}

Menurut Cohen dan Bolton (1994) dalam Hadrian J (2008), autisme dapat diklasifiksikan menjadi beberapa bagian berdasarkan gejalanya. Klasifikasi ini dapat diberikan melalui Childhood Autism Rating Scale (CARS). Skala ini menilai derajat kemampuan anak untuk berinteeraksi dengan orang lain, melalui imitasi, memberikan respon emosi, penggunaan tubuh dan objek, adaptasi terhadap perubahan, memberikan respon visual, pendengaran, pengecap, penciuman dan sentuhan. Selama itu CARS juga menilai derajat kemampuan otak dalam perilaku takut, gelisah, melakukan komunikasi verbal dan nonverbal, aktifitas konsistenisasi respon intelektual dan penampilan menyeluruh. Pengklasifikannya adalah sebagai berikut : 


\section{Sri Sunarsih}

\section{Autis ringan}

Pada kondisi ini anak autis masih menunjukan adanya kontak mata walaupun tidak berlangsung lama. Anak autis ini dapat memberikan sedikit respon ketika dipanggil namanya, menunjukan ekspresi-ekspresi muka, dan dalam berkomunikasi secara dua arah meskipun terjadinya hanya sesekali.

Tindakan-tindakan yang dilakukan masih bisa dikendalikan dan dikontrol dengan mudah, karena perilaku ini dilakukan hanya sesekali saja, sehingga masih bisa dengan mudah untuk dikendalikan.

\section{Autis sedang}

Pada kondisi ini anak autis masih menunjukan sedikit kontak mata, namun tidak memberikan respon ketika namanya dipanggil. Tindakan agresif dan hiperaktif, menyakiti diri sendiri, acuh dan gangguan motorik yang stereotifik cenderung agak sulit dikendalikan namun masih tetap bisa dikendalikan.

\section{Autis berat}

Autis yang berada pada kategori ini menunjukan tindakan-tindakan yang sangat tidak terkendali. Biasanya anak autis memukul-mukulkan kepala ke tembok secara berulangulang dan terus-menerus tanpa henti. Ketika orang tua berusaha mencegah. Namun anak tidak memberikan respon dan anak tetap melakuukannya, bahkan dalam kondisi berada dipelukan orang tuanya, anak autis tetap memukul-mukulkan kepalanya. Anak akana berhenti jika merasa sudah kelelahan kemudian langsung tertidur. Kondisi yang lain yaitu anak terus berlarian didalam rumah sambil menabrakan tubuhnya ke dinding tanpa berhenti hingga larut malam, keringat bercucuran disekujur tubuhnya, anak terlihat sudah sangat kelelahan dan tak berdaya. Tetapi masih terus berlari dn terus menangis. Seperti ingin berhenti, tapi tidak mampu karena itu semua diluar kontrolnya. Hingga akhirnya anak terduduk dan tertidur kelelahan.

\section{Pola Belajar Siswa Autis}

Menurut Hadis (2006) terdapat beberapa pola belajar anak autis diantaranya:

1. Rote learner, yaitu anak cenderung menghafalkan informasi apa adanya tanpa memahami makna simbol yang dihafalkan. 


\section{Pemanfaatan Media Bergambar Pada Pembelajaran Subtema Hewan}

Disekitarku Terhadap Proses Pembelajaran Siswa Autis

2. Gestalt learner, yaitu anak cenderung melihat sesuatu secara keseluruhan, misalnya menghafalkan kalimat-kalimat secara utuh tanpa mengerti arti kata perkata yang terdapat pada kalimat tersebut.

3. Visuallearner yaitu anak mudah memahami sesuatu yang dilihat daripada yang mereka dengar, misalnya lebih senang mempelajari buku yang dilengkapi dengan gambar, lebih senang melihat gambar di televisi ( TV) daripada mendengarkan radio.

4. Hands on leaner, yaitu anak senang mencoba melakukan sesuatu dan mendapatkan pengetahuan dari pengalaman mencobanya tersebut.

5. Auditory learner, yaitu senang bicara dan lebih mudah memahami sesuatu yang mer- eka dengar daripada yang mereka lihat.

Dengan mengetahui pola belajar yang cocok untuk masing-masing anak autis, maka guru diharapkan dapat menyesuaikan proses penyampaian pengetahuan dan informasi dengan pola belajar anak autis tersebut.

\section{Pengertian Media Pembelajaran}

Media adalah bentuk jamak dari medium yang berasal dari bahasa latin medius yang berarti tengah. Dalam bahasa Indonesia kata medium diartikan sebagai "antara' atau "sedang" (Latuheru, 1988: 14). Pengertian media pembelajaran menurut Latuheru (1988: 14) adalah semua alat (bantu) atau benda yang digunakan untuk kegiatan belajar mengajar, dengan maksud menyampaikan pesan (informasi) pembelajaran dari sumber (guru maupun sumber lain) kepada penerima (dalam hal ini anak didik atau warga belajar). Sadiman (2008: 7) menjelaskan media pembelajaran adalah segala sesuatu yang dapat digunakan untuk menyalurkan pesan dari pengirim kepenerima pesan. Dalam hal ini adalah proses merangsang pikiran, perasaan, dan minat serta perhatian siswa sehingga proses belajar dapat terjalin.

Azhar (2011) media pembelajaran adalah alat bantu pada proses belajar baik di dalam maupun diluar kelas, lebih lanjut dijelaskan bahwa media pembelajaran mengandung materi intruksional di lingkungan siswa yang dapat merangsang siswa untuk belajar. Dari pendapatpendapat diatas, dapat disimpulkan pengertian media pembelajaran sebagai alat bantu mengajar untuk menyampaikan materiagar pesan lebih mudah diterima dan menjadikan siswa lebih termotivasi dan aktif.

Dari beberapa pendapat para ahli di atas, maka dapat disimpulkan bahwa sesuatu yang dapat menyalurkan pesan, merangsang pikiran, perasaan dan kemauan yang dapat mendorong 


\section{Sri Sunarsih}

minat peserta didik sebagai terciptanya proses menerima informasi, pengetahuan, keterampilan, sikap atau belajar terhadap peserta didik.

\section{Media Pembelajaran untuk Siswa Autis}

Media pembelajaran yang dapat digunakan dalam proses pembelajaran siswa autis ada bermacam-macam, antara lain :

\section{Menggunakan gambar}

Langkah paling simpel untuk mengajarkan sesuatu bagi anak penyandang autisme adalah dengan menggunakan gambar. Misalnya, ketika ingin melatih anak autis untuk membaca atau berhitung. Pengajar harus menyiapkan properti berupa gambar-gambar yang bisa membantunya mengerti angka atau huruf. Dengan begitu, anak autis akan lebih mudah mengingat huruf-huruf atau angka-angka yang sudah diajarkan.

Menurut Daryanto (2010 : 29) bahwasanya media bergambar kartu adalah sekelompok media yang berwujud benda asli baik benda hidup maupun benda mati yang dapat digunakan untuk menyalurkan pesan dari pengirim ke penerima sehingga dapat merangsang pikiran, perasaan, perhatian dan minat siswa terhadap proses pembelajaran.

\section{Dengan bercerita}

Cerita bisa digunakan sebagai media belajar anak autis. Misalnya, ketika pengajar ingin menceritakan tentang cara kerja mobil. Selain membutuhkan gambar-gambar mobil, pengajar juga harus bisa membacakan cerita-cerita yang berhubungan dengan mobil, entah cara kerjanya, jenis-jenisnya, maupun cara-cara penggunaannya.

\section{Menggunakan video}

Anak autis akan mudah bosan ketika pengajar banyak memberikan penjelasan atau terlalu banyak menerangkan. Hal inilah yang kemudian menyebabkan mereka tidak bisa diam, berlarian, atau bahkan keluar dari kelas. Cara yang paling efektif untuk mengatasi masalah ini adalah menjadikan video sebagai media belajar. Caranya, dengan memutarkan videovideo yang sifatnya edukasi atau medidik. Biasanya, di dalam video-video tersebut bisa disisipi pelajaran berhitung ataupun mengeja. Inilah salah satu trik untuk mengajar anak autis yang cenderung bisa diterima mereka.

\section{Berkesenian}

Salah satu yang tergolong baik untuk diajarkan pada anak autis adalah tentang kesenian. Beberapa jenis kesenian seperti menggambar, melukis, memahat, menari, bernyanyi, atau 


\section{Pemanfaatan Media Bergambar Pada Pembelajaran Subtema Hewan}

Disekitarku Terhadap Proses Pembelajaran Siswa Autis

bahkan bermain musik akan sangat baik untuk dijadikan media belajar. Misalnya dengan menari, anak-anak autis akan memahami irama, ketukan, dan hitungan. Dengan begitu, secara tidak langsung mereka sudah belajar berhitung. Bisa juga menerapkan pemahaman atas benda-benda disekitar dengan cara menggambar dan mewarnai. Sediakan gambar benda-benda di sekitar yang belum diwarnai. Ajaklah anak-anak autis untuk belajar menghubungkan garis dan mewarnai gambar tersebut.

\section{Penggunaan Media Gambar Dalam Pembelajaran}

Media bergambar yang baik sebagai media pendidikan adalah media gambar yang cocok dan sesuai dengan tujuan pembelajaran. Ada beberapa syarat yang perlu dipenuhi oleh gambar yang baik sehingga dapat dijadikan sebagai media pendidikan.

\section{Autentik}

Gambar tersebut harus secara jujur melukiskan situasi seperti kalau orang melihat benda sekitarnya.

2. Sederhana.

Komposisi gambar hendaknya cukup jelas menunjukkan poin-poin pokok dalam gambar.

3. Ukuran Relatif.

Gambar dapat membesarkan atau memperkecil objek/benda sebenarnya. Apabila gambar tersebut tentang benda / objek yang belum dikenal atau pernah dilihat anak maka sulitlah membayangkan berapa besar benda atau objek tersebut.

4. Gambar sebaiknya mengandung gerak atau perbuatan.

Gambar yang baik adalah gambar yang memperlihatkan aktifitas tertentu.

1. Gambar yang bagus gambar yang bagus dilihat dari sudut seni.

2. Gambar yang baik sesuai dengan tujuan pembelajaran yang akan dicapai.

\section{Pembelajaran Tematik}

Pada dasarnya pembelajaran tematik atau tema terpadu merupakan terapan pembelajaran terpadu. Pembelajaran tematik yang diharapkan berkembang di sekolah dasar mengarah pada penggabungan dari webbed model (model jaring laba-laba) dan integrated model (model terpadu). Istilah pembelajaran tematik pada dasarnya adalah model pembelajaran terpadu yang menggunakan tema untuk mengaitkan beberapa mata pelajaran sehingga dapat memberikan pengalaman bermakna pada siswa (Depdiknas dalam Trianto, 2011). 


\section{Sri Sunarsih}

Sementara Trianto (2011: p.152) menyatakan pendapatnya bahwa pembelajaran tematik menawarkan model-model pembelajaran yang menjadikan aktivitas pembelajaran itu relevan dan penuh makna bagi siswa dengan memberdayakan pengetahuan dan pengalaman siswa untuk membantu memahami dunia nyatanya. Perolehan keutuhan belajar, pengetahuan dan kebulatan pandangan tentang kehidupan dan dunia nyata hanya dapat direfleksikan melalui pembelajaran terpadu (Willian dalam Tianto, 2011).

Selanjutnya Majid (2014: 87) berpendapat menyatakan bahwa pembelajaran tematik menggabungkan suatu konsep dalam beberapa bidang studi yang berbeda dengan harapan anak akan belajar lebih baik dan bermakna.

Berdasarkan beberapa pendapat di atas, dapat ditarik kesimpulan bahwa pendekatan pembelajaran tematik adalah suatu pendekatan pembelajaran, yang mengangkat suatu tema tertentu untuk mengikat beberapa materi pelajaran. Tema yang dipilih harus berkaitan erat

dengan pengalaman nyata siswa dalam kehidupan sehari-hari, sehingga pembelajaran yang dialami siswa dapat memberikan pengalaman bermakna bagi diri siswa sendiri. menunjukkan perilaku yang repetitif, mengalami gangguan perilaku agresif dan hiperaktivitas sekaligus sensoris, serta mengalami perkembangan yang terlambat, tidak normal ataupun tidak seimbang.

\section{Metode Penelitian}

\section{Setting Penelitian}

Penelitian ini merupakan penelitian yang didesain dalam bentuk pemanfaatan media bergambar pada pembelajaran subtema hewan di sekitarku terhadap proses pembelajaran siswa autis dan hasilnya akan diuraikan dalam bentuk deskriptif kualitatif. Penelitian ini dilakukan di SDIT Insan Mulia Merangin dan di rumah siswa autis. Tahun Pelajaran 2019/2020 yang terletak di Kabupaten Merangin dengan informan penelitian ini meliputi Kepala Sekolah, Guru Kelas dan orang tua siswa aautis dengan didasari atas pertimbangan sebagai berikut:

1) Bahwa SDIT Insan Mulia Merangin merupakan sekolah dasar Islam Terpadu satu-satunya di kota Bangko.

2) SDIT Insan Mulia Merangin satu-satunya sekolah yang menerima siswa berkebutuhan khusus yaitu siswa autis.

3) Menjadi salah satu lembaga pendidikan dasar yang memadukan kurikulum Diknas dan Kurikulum berbasis Agama Islam. Penelitian ini dilaksanakan selama 5 bulan dimulai dari 
bulan Februarii 2020 sampai bulan Juni 2020.

\section{Teknik Pengumpulan Data}

Data pada penelitian ini dikumpulkan melalui observasi, wawancara dan dokumentasi. penulis menggunakan observasi partisipan, artinya peneliti mengamati secara langsung terhadap apa yang di observasi. Data ini bersumber dari interaksi peneliti dengan siswa autis SDIT Insan Mulia Merangin dan didiskusikan bersama guru kelas atau selama melakukan tindakan. Teknik observasi (pengamatan) di lapangan, yaitu pada saat kegiatan pembelajaran pada berfikir simbolik dengan pemanfataan media bergambar. Dalam pengamatan ini akan diketahui tingkat perkembangan peserta didik, sebagaimana kriteria penilaian kemampuan belajar siswa autis berikut ini :

1) (BM) artinya belum mampu : bila siswa melakukannya harus dengan bimbingan guru atau dicontohkan oleh guru dengan score 1 dengan ciri (*)

2) (CK) artinya cukup mampu : bila siswa melakukannya masih diingatkan atau dibantu oleh guru dengan score 2 dengan ciri $(* *)$

3) (M) artinya: Mampu : bila siswa sudah dapat melakukannya secara mandiri dan konsisten tanpa hars diingatkan atau dicontohkan oleh guru dengan score 3 dengan ciri (***)

4) (SM) artinya sangat mampu : bila anak sudah dapat melakukannya secara mandiri dan sudah dapat membantu temannya yang belum mencapai kemampuan sesuai indicator yang dihrapkan dengan score 4 dengan ciri $(* * * *)$

Jenis wawancara yang digunakan adalah wawancara tidak terstruktur. Artinya peneliti mengajukan pertanyaan-pertanyaan secara lebih bebas dan leluasa, tanpa terikat oleh suatu susunan pertanyaan yang telah dipersiapkan sebelumnya, meski begitu, peneliti juga menggunakan panduan wawancara yang berisi butir-butir pertanyaan yang diajukan kepada informan yaitu Kepala Sekolah guru kelas dan orang tua siswa autis.

Teknik dokumentasi ini salah satu teknik pengumpulan data yang peneliti gunakan dalam penelitian untuk menganalisis data proses pembelajaran subtema hewan di sekitarku terhadap siswa auis SDIT Insan Mulia Merangin dengan memanfaatkan media bergambar pada saat proses pembelajaran sedang berlangsung. Dokumentasi berupa foto dan video aktivitas pembelajaran berlangsung hingga evaluasi perkembangan peserta didik.

Analisis data yang digunakan dalam penelitian ini adalah deskriptif kualitatif artinya data yang diperoleh dari penelitian tentang pemanfaatan media bergambar pada pembelajaran 


\section{Sri Sunarsih}

subtema hewan disekitarku terhadap proses pembelajaran siswa autis SDIT Insan Mulia Merangin melalui lembar observasi dan dilaporkan apa adanya kemudian di analisis secara deskriptif untuk mendapat gambaran mengenai fakta yang ada. Proses analisis data dalam penelitian ini bertujuan untuk menjawab pertanyaan penelitian.

Aktivitas dalam analisis data dimulai dengan pengumpulan data, reduksi data, penyajian data, dan penarikan kesimpulan/verifikasi. Proses analisis data dilakukan secara terus menerus didalam proses pengumpulan data selama penelitian berlangsung.

\section{Hasil Dan Pembahasan}

\section{Pemanfaatan Media Gambar Terhadap Kemampuan Bahasa Siswa Autis (Menyebutkan Nama-Nama Hewan)}

Pada kegiatan ini, bu Husnul selaku guru kelas telah terlebih dahulu menyampaikan pembelajaran tentang tema 6 subtema hewan disekitarku dengan memanfaatkan media buku paket. Dalam subtema hewan disekitarku, bu Husnul meminta semua siswa untuk menyebutkan hewan yang pada buku paket tersebut. Hasil observasi yang dilakukan oleh peneliti, siswa normal terlihat antusias untuk menjawab pertanyaan dari bu Husnul Bahkan beberapa anak sudah paham dan bisa menyebutkan nama-nama hewan yang terdapat pada buku paket tersebut dengan benar dan jelas. Akan tetapi, Az tidak menjawab. Az hanya berdiam diri di tempat duduknya kadang sesekali kepalanya disandarkan di atas meja. Awal diberikan media bergambar buku paket, Az belum mampu menyebutkan nama-nama hewan yang terdapat dalam buku paket Setelah diberikan materi hewan disekitrku secara berulang-ulang dan konsisten dengan didampingi bu Husnul, akhirnya Az mampu menyebutkan nama hewan yang ditunjuk oleh bu Husnul yang terdapat pada buku paket, ada 4 ekor nama hewan yaitu sapi, ayam, kucing dan burung, yang artinya Az dapat melakukan instruksi yang diberikan oleh guru jika dibantu dan didampingi secara beulang-ulang dan konsisten oleh guru dalam kemampuannya menyebut nama hewan yang ada pada buku paket namun dengan verbal yang masih belum jelas.

Berikutnya peneliti meminta bu Husnul untuk merubah mengubah objek media bergambar, yang semula buku paket di ganti menjadi kartu bergambar. Dimana pengamatan ini dilaksanakan di rumah siswa Autis di BTN Vila Mandiri Sungai Ulak Bangko. dengan proses pembelajaran di lakukan oleh bu Husnul secara privat, sebelum belajar bu Husnul meminta Az untuk berdoa terlebih dahulu. Kemudian bu Husnul meminta Az untuk menyebutkan hewan apa 
saja yang pernah di temukan Az di rumah. Az balik bertanya dengan "apa?. Bu Husnul mengulangi pertanyaannya. Baruulah Az paham, lalu Az menjawab “ayam”. Ketika bu Husnul mengeluarkan kartu-kartu pembelajaran subtema hewan di sekitarku (ayam, kelinci, kucing, sapi, burung), raut wajah Az berubah lalu bertanya "ini apa?" bu Husnul menjawab "ini kartu untuk belajar”. Dengan raut wajah cerah Az mengambil kartu yang diberika oleh bu Husnul. Lalu bu Husnul menannyakan nama-nama hewan yang ada didalam kartu tersebut. Sebelum belajar bu Husnul meminta Az untuk berdoa terlebih dahulu. Selanjutnya bu husnul meminta Az menyebutkan nama-nama hewan yang pernah ia temui dan ia ketahui.

Pada kegiatan pemanfaatan media bergambar kartu ini, Az lebih capat menangkap materi yang disampaikan oleh bu Husnul. Az dapat menyebutkan nama-nama hewan yang ada dalam kartu. Bahkan Az juga ikut bernyanyi walau dengan verbal yang kurang jelas. Berdasarkan wawancara dengan bu Husnul bahwa Az sudahh belajar melalui buku paket tentang hewan disekitarku, ingatan Az sangat kuat. Karena materi ini sudah diberikan beberapa kali walau dengan media yang berbeda, tapi materinya sama. Dapat peneliti simpulkan bahwa Az dapat menyebutkan nama-nama hewan seperti ayam, kelinci, kucing, sapi dan burung.

Ketika bu Husnul mengubah media pembelajaran dengan media slide power point dan video lagu, dimana bu Husnul menampilkan gambar-gambar menggunakan slide Pada dan video lagu "ayamku". Az diminta untuk menyimak gambar dan lagu dalam video. Kemudian bu Husnul menyebutkan nama-nama hewan yang ditunjuk bu Husnul dengan sambil terus didampingi. Az sudah mampu menyebutkan nama-nama hewan dalam slide power point. menunjukan ke arah. Dan mengikuti irama lagu "ayamku” dalam video tersebut.

Berdasarkan pengamatan peneliti menemukan bahwa Az lebih antusias belajar menggunakan tampilan slide power point dan video daripada menggunakan buku paket maupun kartu, hal ini terlihat makin banyaknya kosa kata Az dalam menyebutkan nama hewan-hewan selain dari materi hewan disekitarku. Seperti kuda, kambing, domba, bebek, angsa dan beberapa hewan lainnya. Namun Az susah sekali mengidentifikasi keledai, karena penampilannya yang mirip dengan kuda. Disamping itu keledai juga tidak ada di wilayah sekitar tempat tinggal. Dari sini dapat disimpulkan bahwa pemanfaatan media visual dapat meningkatkan kemampuan belajar siswa autis dalam kemampuan berbahasa. Pemanfaatan media vidual ini juga ditegaskan oleh Sri Anita, (2010: 7) media pembelajaran menempati posisi yang cukup penting sebagai salah satu komponen sistem pembelajaran. Tanpa media, komunikasi tidak akan terjadi dan 


\section{Sri Sunarsih}

proses pembelajaran sebagai proses komunikasi juga tidak akan bisa berlangsung secara optimal. Media pembelajaran adalah komponen integral dari sistem pembelajaran. Dari pendapat di atas dapat disimpulkan bahwa media pembelajaran adalah segala sesuatu yang dapat menyalurkan pesan, dapat merangsang pikiran, perasaan, dan kemauan peserta didik sehingga dapat mendorong terciptanya proses belajar pada diri peserta didik. Dunia pendidikan yang membutuhkan media seperti buku teks, bahan belajar yang dibuat oleh guru dan "audio-visual".

\section{Pemanfaatan Media Gambar Terhadap Kemampuan Akademik (Menggunakan Gambar-}

\section{Gambar Hewan Untuk Menghitung)}

Pada tahap ini Bu Husnul memintaa Az mengeluarkan buku tulis dan alat tulis lainnya di dalam tasnya. Bu Husnul meminnta Az menuliskan semua nama-nama hewan yang terletak dibagian belakang kartu. Kemudian bu Husnul meminta Az menunjukan kartu sesuai dengan nama hewan yang disebutkan oleh bu Husnul. Az dapat menyebutkan kelima ekor hewan yang ada pada kartu gambar.Kemudian ketika bu Husnul meminta Az menghitung jumlah ayam, jumlah kelinci, jumlah burung, jumlah kucing, jumlah sapi. Peneliti menemukan Az menjawab dengan antusias. memperlihatkan kepada bu Husnul setiap kartu yang dipegang, sambil bersuara “ini?”. Maksudnya Az menanyakan hewan apa yang ada di kartu yang dia pegang. Bu Husnul menjawab dan mengarahkan Az pada tulisan nama-nama hewan dalam setiap kartu kemuddian bergantian bu Husnul meminta Az menunjukkan gambar hewan sesuai dengan dengan namanya. Az mengikuti instruksi yang diberikan oleh bu Husnul. Dengan verbal yang sedikit lebih jelas dari hari sebelumnya, Az mampu menghitung jumlah seluruh hewan-hewan yang ada didalam kartu.

Pada kegiatan berikutnya bu Husnul meminta semua siswa termasuk Az untuk membuka buku paket subtema hewan di sekitarku halaman 1, selanjutnya bu Husnul menyebutkan sebuah nama hewan yang terdapat didalam byku halaman 1 tersebut dan meminta anak untuk menunjukkan gambar yang sesuai dengan yang disebutkan oleh bu Husnul. Hasil observasi terlihat ada beberapa siswa yang mampu menyebutkan gambar sambil menunjukan gambar pada buku paket. Ada dua siswa yang permisi ke kamar kecil, peneliti menemui Az hanya diam saja duduk di tempat duduknya, ketika bu Husnul menanyakan hal yang sama pada Az, Az belum mampu untuk menunjukan gambar yng disebutkan oleh bu Husnul. Az terlihat tidak menunjukan ekspresi tertarik pada pelajaran kali ini.

Hasil observasi ini tersebut juga diperkuat dengan hasil wawancara pada tanggal 20 
Februari 2020 dengan Ibu Husnul yang menyampaikan bahwa "Kemampuan Az masih kurang dalam menyebutkan sesuatu yang diminta oleh guru berbeda dengan teman-temannya yang lain. $\mathrm{Az}$ lebih senang menyendiri ketika pelajaran dilaksanakan secara bersama-sama. Artinya Az belum mampu untuk mengikuti proses pembelajaran dengan buku paket.

Menurut Ibu bu Husnul "Az mampu mengikuti proses pembelajaran jika pembelajaran yang dilakukan secara berulang-ulang dan konsisten, hal ini karena kecenderungan $\mathrm{Az}$ menyendiri dan sering menarik diri dari pergaulannya dengan temannya.

Dari hasil observasi dan wawancara yang peneliti lakukan kemudian peneliti melakukan pemeriksaan kembali terhadap data yang diperoleh menggunakan triangulasi sehingga dapat disimpulkan bahwa Az sebagai siswa autis kelas 2B dalam pemanfaatan media buku paket terlihat belum mampu dalam proses perkembangan belajarnya. Menurut Ibu bu Husnul "Az mampu mengikuti proses pembelajaran jika pembelajaran yang dilakukan secara berulang-ulang dan konsisten, hal ini karena kecenderungan $\mathrm{Az}$ menyendiri dan sering menarik diri dari pergaulannya dengan temannya.

Dari hasil observasi dan wawancara yang peneliti lakukan kemudian peneliti melakukan pemeriksaan kembali terhadap data yang diperoleh menggunakan triangulasi sehingga dapat disimpulkan bahwa $\mathrm{Az}$ sebagai siswa autis kelas 2B dalam pemanfaatan media buku paket terlihat belum mampu dalam proses perkembangan belajarnya.

Berikutnya bu Husnul mendampingi Az dengan duduk di samping Az. Memperlihatkan tampilan slide power points dan video lagu "ayamku", bu Husnul meminta Az menghiung jumlah ayam-ayam, kelinci, kucing, sapi dan burunng yang terdapat dalam tampilan slide power point. Dari pengamatan ini ternyata Az mampu menjawab pertanyaan bu Husnul, Az mampu menghitung semua ayam, kelinci, kucing, sapi maupun burung dalam gambar power point maupun dalam video. Kemampuan menghitung Az ini dikarenakan berlakuan yang diberikan oleh bu Husnul secara berulang-ulang dan konsisten sehingga hasil yang diharapkan sesuai dengan target penelitian.

Dari penjelasan bu Husnul bahwa pemanfaatan media visual dalam kemampuan berhitung siswa autis dengan dilengkapi lambang-lambang bilangan yang terdapat pada gambar. Dengan warna dan bentuk yang menarik. Dan siswa autis pun sangat berkembang kemampuan belajarnya apabila dalam proses pembelajaran sendiri selalu didampingi oleh guru dan dalam suasana yang ruangan yaang nyaman dengan sistem private. 


\section{Kesimpulan}

Berdasarkan hasil pembahasan diatas. dapat ditarik kesimpulan yaitu setelah diberilakan kesempatan belajar selama enam belas kali dan di lakukan secara berulang-ulang dan konsisten dengan menggunakan media bergambar terdapat peningkatan perkembangan belajar pada proses pembelajaran siswa autis pada kemampuan bahasa (menyebutkan nama hewan-hewan disekitarku) dan kemampuan akademik (menggunakan media gambar untuk menghitung).

Penulis menyarankan agar pemanfaatan media bergambar dapat diimplementasikan ke dalam program pembelajaran disekolah khususnya bagi siswa autis.

\section{Daftar Rujukan}

Abdul Majid. (2014). Strategi Pembelajaran. Bandung: PT Remaja Rosdakarya.

Abdolmuhammad, M dan A. Wright. (1997).. An Examinatio of Effect of Experience and Task Complexity on Audit Judgment. Journal of Accounting Review. LXII(1)1: 1-13/

Akhmad Sudrajat. (2007). Pengertian Pendekatan, Strategi, Metode, Teknik dan Model Pembelajaran. Bandung: Sinar Baru Algensindo.

Arsyad, A. (2014). Media Pembelajaran. Jakarta. PT. Raja Grafindo Perkasa

Azwandi, Yosfan. (2005). Mengernal dan Membantu Penyandang Autisme. Jaakarta. Departemen Pendidikan Nasional. Dirjen Dikti.

Borich, Gary D. (1994). Observation Skill for Effective Teaching: Research-Based Practice. Seventh Edition. New York: M M Publishing Company.

Bolton, P. dan Boron-Cohen, S. (1994). Autism : The Fact. New York : Oxford University Press Ink

Chiapetta, Eugene L. (1997). Inquiry-Based Science: Strategies and Techniques for Encouraging Inquiry in the Classroom. Journal.

Connie (2016). Learning in Encyclopedia of Educational Research, Richard E. Mayer

Daryanto (2016). Media Pembelajaran. Yogyakarta. Gawa Media.

Dede. A (2016). Implikasi Pembelajaran Tematik. Dalam diakses tanggal 21 Juni 2020 09:02

Depdiknas. (2006). Kurikulum Tingkat Satuan PendidikaDn. Jakarta: Balai Pustaka. 
Dimyati Mudjiono, (2006), Belajar dan Pembelajaran. Jakarta. PT. Rieneka Cipta

Farahdiba (2013), Autism Care Center dengan Pendekatan Behavior Architecture. Jakarta

Guntur Tarigan, Hendry, (1986). Menyimak sebagai suatu keterampilan Berbahasa. Angkasa Bandung.

Hadrian, J (2008). Autisme http//johaneshadrian.wordpress.com2008/08/autisme// (diakses 7 Juni 2017)

Keraf, Gorys. (2001). Argumentasi dan Narasi. Jakrta. PT. Gramedia Pustaka Utama.

Khalid, Tahsin. (2010). An Integrated Inquiry Activity in an Elementary Teaching Methods Classroom. Journal. Science Activities, 47: 29-34. ISSN 0036-8121.

Kurdi, (2009), Strategi dan Tehnik Pembelajaran Bagi Anak . Forum Kependidikan Volume 29. No 1 September.

Long, Richard. (2009). Strategy Compersation in Canada Education Limited. 2009

Mahendra, Krisnatuti D, Tobing A, Boy, (2008). Care Your Self Diabetes Melitus. Jakarta. Penebar Plus

Marganingtiyas, P, (2014). Atificial Intelligence (Teknik dan Aplikasinya). Yogyakakrta. Graha Ilmu.

Muhammad, Jamila K.A. (2008). Special Education for Special Children: Panduan Pendidikan Khusus Anak-anak dengan Ketunaan dan Learning Disabilities. Jakarta: Hikmah

Plowman \& Smith. (2008). Exercise Phsiology for Health, Fitness, and Performance. New York: Lippincot William \& Wilkins.

Poerwadarminta, Wilfridus Josephus Sabarija. (1997). Kamus Umum Bahasa Indonesia. Jakarta: Balai Pustaka.

Rohmah, Noer. (2012). Psikologi Pendidikan. Yogyakarta. Teras.

Santoso, Subhan Adi, 2020. Media Pembelajaran Pendidikan Agama Islam Era Industri 4.0. Yogyakarta: Deepublish

Saryono, (2010). Metode penelitian kualitatif. PT. Alfabeta. Bandung

Suharsimi Arikunto. (2008). Dasar-dasar Evaluasi Pendidikan. Jakarta: Bumi Aksara.

Saul McLeod (2009) dalam Elliott et al.,(2000:256). Educational Psychology Effective Teaching, Effeective Learning 3rd edition. United State of America Mc Graw Hill Companies

Susanti, Leni. (2014). Kisah-kisah Motivasi Untuk Anak Berkebuyuhan Khusus Autis. Yphyakarta. Javalitera. 


\section{Sri Sunarsih}

Sutirjo dan Sri astuti malik. (2005). Tematik Pembelajaran Tematik dalam Kurikulum 2004. Malang. Bayumedia Peblishing.

Syaiful Sagala. (2011). Konsep dan Makna Pembelajaran. Bandung: PT Alfabeta.

Safaria, Triantoro, (2005), Autis. Pemahaman Baru untuk Hidup Bagi Orang Tua. Jogjakarta. Graha Ilmu

Tarigan dan Tarigan (Veskurisyanti, GA. (2008). Deteksi dini pada anak autis. Jurnal pendidikan anak. Yogyakarta. Pustaka Anggrek.

Wanapri Pangaribuan. (2012). Metode Pendidikan Berkarakter oleh Ayah pada Anak untuk Keberhasilan Anak di Sekolah dan Dipekerjaan. Majalah/ Jurnal Generasi Kampus. Volume 5, Nomor 1, April 2012.

Yuwono, J. (2009). Memahami Anak Autis. Bandung. CV. Alfbeta .

Yuwono, J. (2012). Memahami Anak Autis. Bandung. CV. Alfbeta . 